\title{
The IODP Nankai Trough Seismogenic Zone Experiment
}

\author{
by Harold Tobin and Masataka Kinoshita
}

doi:10.2204/iodp.sd.s01.30.2007

\section{Introduction}

The Integrated Ocean Drilling Program's (IODP) Nankai Trough Seismogenic Zone Experiment (NanTroSEIZE) attempts to drill into, sample, and instrument the updip portion of the Nankai subduction megathrust asperity. Access to the interior of active faults in which in situ processes can be monitored and fresh fault zone materials can be sampled is of fundamental importance to the understanding of earthquake mechanics. Great subduction earthquakes (with their accompanying tsunamis) represent one of the greatest natural hazards on the planet. Accordingly, drilling into and instrumenting an active interplate seismogenic zone was identified as a very high priority in the IODP Initial Science Plan, 2001. Through a decade-long series of international workshops, a consensus was made that the Nankai Trough subduction zone was an ideal place to attempt drilling the seismogenic plate interface. The first stage of NanTroSEIZE drilling operations is now scheduled for the late summer of 2007. It involves parallel deployment of the new U.S. Scientific Ocean Drilling Vessel (SODV) and the riser vessel Chikyu.

Thefundamentalgoal of the NanTroSEIZE science plan (Tobin and Kinoshita, 2006; Kinoshita et al., 2006) is the creation of a distributed observatory spanning the updip limit of seismogenic and tsunamigenic behaviors at a location where great subduction earthquakes occur, allowing us to observe the hydrogeologic behavior of subduction megathrusts and the aseismicto-seismic transition of the megathrust system. This will involve drilling of key elements of the active plate boundary system at several locations off the Kii Peninsula of Japan from the shallow onset of the plate interface to depths where earthquakes occur (Figs. 1 and 2). At this location, the plate interface and active megasplay faults implicated in causing tsunami are accessible to drilling in the region of coseismic rupture in the 1944 Tonankai magnitude 8.0 earthquake. The most ambitious objective is to access and instrument the Nankai plate interface within the seismogenic zone. The science plan entails sampling and long-term instrumentation of (a) the inputs to the subduction conveyor belt, (b) faults that splay from the plate interface to the surface that may accommodate a major portion of coseismic and tsunamigenic slip, and (c) the main plate interface at depths of $\sim 4-6 \mathrm{~km}$.

In addition to NanTroSEIZE, there is a burgeoning interest in active fault drilling, represented by the San Andreas Fault Observatory at Depth (SAFOD), Taiwan Chelungpu Fault Drilling Project (TCDP), Corinth Rift Laboratory (CRL), Nojima Fault Drilling Project, and other active projects on land and at sea (Reches and Ito, 2007). This is taking place in the context of rapidly growing research efforts on the mechanics and dynamics of faulting processes that integrate rock mechanics, seismology, geodesy, frictional physics, and fluid-fault interactions. Despite recent advances, there is at present no unified theory of fault slip to account for earthquake nucleation and propagation, nor to explain the mechanisms of strain across the spectrum of observed deformation rates ranging from seconds to years. Consequently, the question of whether precursor signals exist for major earthquakes, even in theory, remains under discussion. Progress on these topics is severely limited by a lack of information on

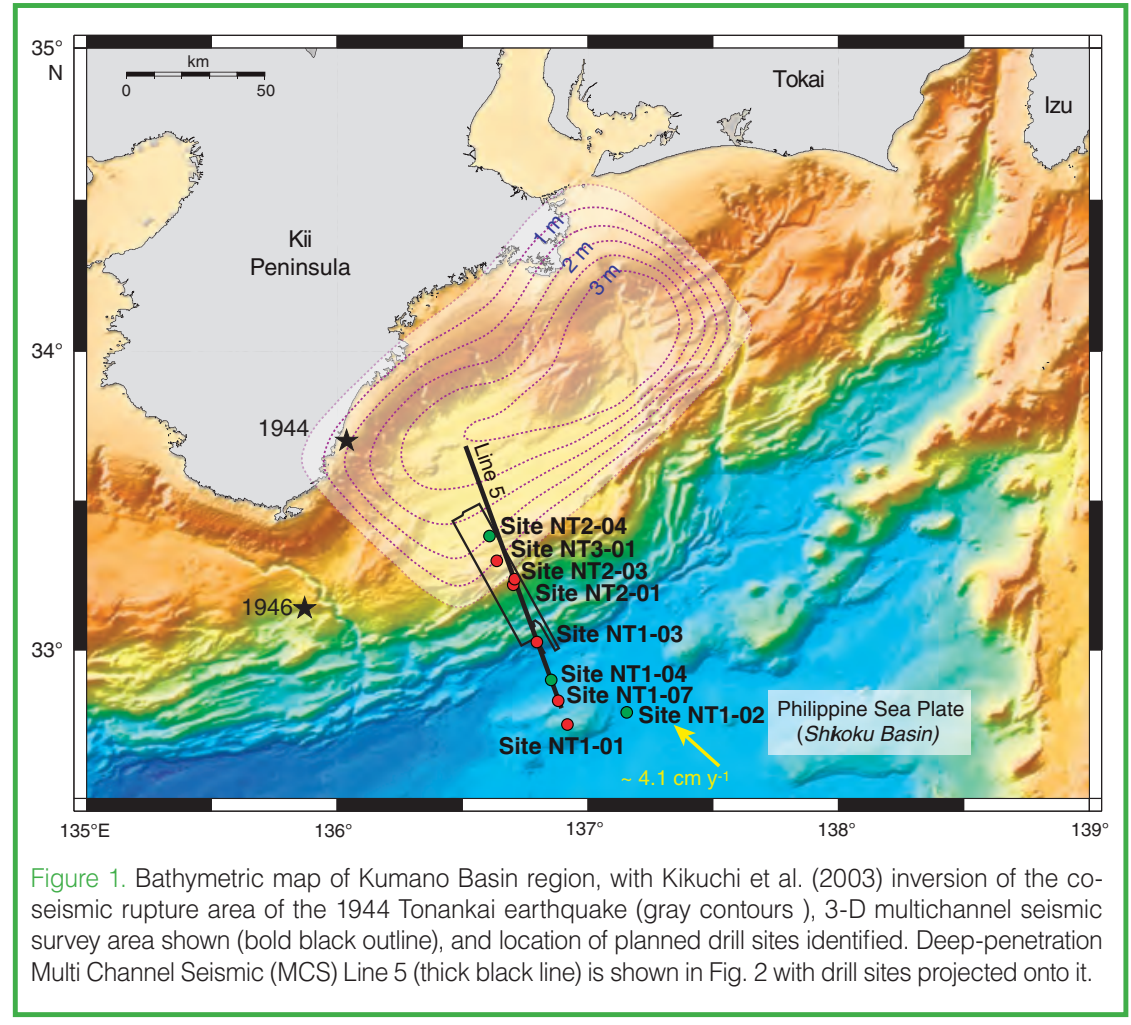




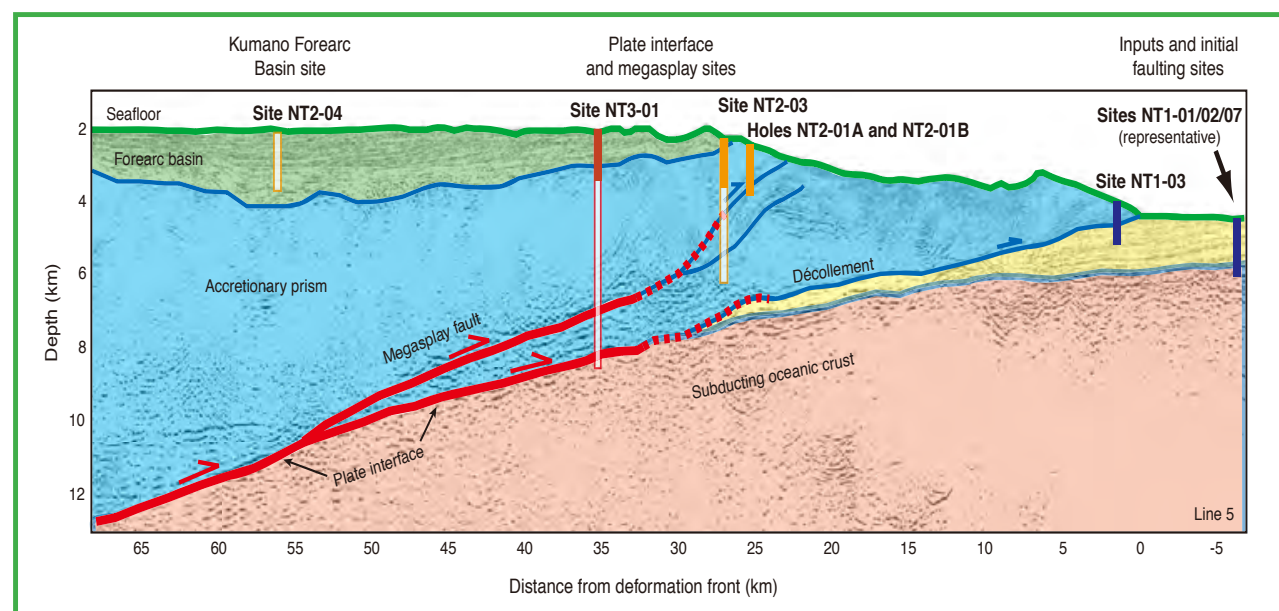

Figure 2. Prestack depth-migrated seismic line 5 of Park et al. (2002), with locations of planned drill sites. Riserless sites planned for Stage 1 drilling are shown in solid color, and riser-drilling sites are shown in outline. Faults labeled with red arrows are inferred possible co-seismic slip zones during 1944 event on basal decollement and mega-splay fault. Vertical exaggeration $=2 x$. ambient conditions and mechanical properties of active faults at depth. Extant rheological models for how faults behave depend on specific physical properties at the fault interface and in the surrounding rock volume. Coefficients of friction, permeability, pore-fluid pressure, state of stress, and elastic stiffness are examples of such parameters that can best (or only) be measured through drilling and through geophysical sensing of the surrounding volume.

\section{Geological and Geophysical Background}

Subduction zones like the Nankai Trough, on which great earthquakes $(M>8.0)$ occur, are especially favorable for study because the entire width (dip extent) of the seismogenic zone ruptures in each great event. Thus, the future rupture area is perhaps more predictable than for smaller earthquakes. The Nankai Trough region is among the beststudied subduction zones in the world. It has a 1300-year historical record of recurring and typically tsunamigenic great earthquakes, including the 1944 Tonankai (M8.1) and 1946 Nankaido (M8.3) earthquakes (Ando, 1975; Hori et al., 2004). The rupture area and zone of tsunami generation for the 1944 event are now reasonably well understood (Baba and Cummins, 2005; Ichinose et al., 2003). Land-based geodetic studies suggest that the plate boundary thrust here is strongly locked (Miyazaki and Heki, 2001). Similarly, the relatively low level of microseismicity near the updip limits of the earthquakes in the 1940s (Obana et al., 2004) implies significant interseismic strain accumulation on the megathrust; however, recent observations of very low frequency (VLF) earthquake event swarms apparently taking place within the accretionary prism in the drilling area (Obara and Ito, 2005) demonstrate that interseismic strain is not confined to slow elastic strain accumulation, but also is released as slow events.

In the Kumano Basin, the seismogenic zone lies $\sim 6000 \mathrm{~m}$ beneath the seafloor (Nakanishi et al., 2002). Slip inversion studies suggest that only here did past coseismic ruptures clearly extend shallow enough for drilling (Baba and Commins, 2005; Ichinose et al., 2003), and, consequently, an updip zone of large slip (asperity) has been identified and targeted. Coseismic slip during events like the 1944 Tonankai earthquake likely occurred on the megasplay fault rather than on the décollement beneath it, though slip on either plane is permissible given the available data. Therefore, the megasplay fault is a primary drilling target equal in importance to the basal décollement zone.

\section{Overall Project Scientific Objectives}

Conditions for stable versus unstable sliding-which define seismic versus aseismic behavior-have long been the subject of research and debate, as has the frictional strength of likely fault zone material. Fault zone composition, consolidation state, normal stress magnitude, pore-fluid pressure, and strain rate may affect the transition from aseismic to seismic slip (Saffer and Marone, 2003). NanTroSEIZE will sample fault rocks over a range of pressure and temperature (P-T) conditions across the aseismicseismogenic transition; the composition of faults and fluids and associated pore pressure and state of stress and will address partitioning of strain spatially between the décollement and splay faults. NanTroSEIZE will also install borehole observatories to provide in situ monitoring of these critical parameters (by monitoring of seismicity, strain, tilt, pressure, and temperature) over time, and test whether interseismic variations or detectable precursory phenomena exist prior to great subduction earthquakes.

The overarching hypotheses to be addressed are as follows:

- Systematic, progressive material and state changes control the onset of seismogenic behavior on subduction thrusts.

- Subduction zone megathrusts are weak faults.

- Within the seismogenic zone, relative plate motion is primarily accommodated by coseismic frictional slip in a concentrated zone.

- Physical properties, chemistry, and state of the fault zone change systematically with time throughout the earthquake cycle.

- The mega splay (out-of-sequence thrust; OOST) thrust fault system slips in discrete events, which may include tsunamigenic slip during great earthquakes. 


\section{Wiring the Seismogenic Fault}

There are several borehole observatories installed on land and at sea. Over 700 on-land borehole observatory stations were installed at NIED (National Institute for Earth Science and Disaster Prevention) around Japanese islands. Basically, stations consist of broadband seismometers and tiltmeters. Comparable seismometer arrays have been deployed at the SAFOD, Nojima, and TCDP sites. Araki et al. (2004) installed a tiltmeter-strainmeter-broadband seismometer system in a seafloor borehole at the forearc of the Japan Trench.

The NanTroSEIZE observatory will be constructed based on all the experience obtained through the above mentioned installations. Since the temperature at $6 \mathrm{~km}$ below sea floor will exceed $150^{\circ} \mathrm{C}$, we anticipate serious difficulties with any instrumentation of the seismogenic megathrust zone. Since good coupling of the instruments to the formation is essential, we need to develop a good clamping method and a good cementing method between the open hole and casing. Significantly tilted holes will prevent instruments from residing within measurable ranges. Wellhead seals are required for safety and environmental reasons, and this reduces the number of feedthroughs of electric and hydraulic conductors across the wellhead. We plan to develop a subseafloor A/D conversion and telemetry system. Finally, borehole data will be connected to a currently developed seafloor cable network off the Kumano area.

The Nankai Trough area poses a big challenge for ultradeep drilling, but it is hoped that the outcome will be much larger than the investment for this project.

\section{References}

Ando, M., 1975. Source mechanisms and tectonic significance of historical earthquakes along the Nankai Trough, Japan. Tectonophysics, 27(2):119-140, doi:10.1016/00401951(75)90102-X.

Araki, E., Shinohara, M., Sacks, S., Linde, A., Kanazawa, T., Shiobara, H., Mikada, H., and Suyehiro, K., 2004. Improvement of seismic observation in the ocean by use of seafloor boreholes. Bull. Seismol. Soc. Am., 94:678-690, doi:10.1785/0120020088.

Baba, T. and Cummins, P.R., 2005. Contiguous rupture areas of two Nankai Trough earthquakes revealed by high resolution tsunami waveform inversion. Geophys. Res. Lett., 32(8): L08305, doi:10.1029/2004GL022320.

Hori, T., Kato, N., Hirahara, K., Baba, T., and Kaneda, Y., 2004. A numerical simulation of earthquake cycles along the Nankai Trough in southwest Japan: lateral variation in frictional property due to the slab geometry controls the nucleation position. Earth Planet. Sci. Lett., 228(3-4):215-226. doi:10.1016/j.epsl.2004.09.033.

Ichinose, G.A., Thio, H.K., Somerville, P.G., Sato, T., and Ishii, T., 2003. Rupture process of the 1944 Tonankai earthquake
(Ms 8.1) from the inversion of teleseismic and regional seismograms. J. Geophys. Res., 108(B10):2497, doi:10.1029/ 2003JB002393.

Kinoshita, M., Moore, G., von Huene, R., Tobin, H., and Ranero, C.R., 2006. The seismogenic zone experiment. Oceanogr., 19:28$38,2006$.

Miyazaki, S. and Heki, K., 2001. Crustal velocity field of southwest Japan: subduction and arc-arc collision. J. Geophys. Res., 106(B3):4305-4326, doi:10.1029/2000JB90031.

Nakanishi, A., Takahashi, N., Park, J.-O., Miura, S., Kodaira, S., Kaneda, Y., Hirata, N., Iwasaki, T., and Nakamura, M., 2002. Crustal structure across the coseismic rupture zone of the 1944 Tonankai earthquake, the central Nankai Trough seismogenic zone. J. Geophys. Res., 107(B1):2007, doi:10.1029/2001JB000424.

Obana, K., Kodaira, S., and Kaneda, Y., 2004. Microseismicity around rupture area of the 1944 Tonankai earthquake from ocean bottom seismograph observations. Earth Planet. Sci. Lett., 222 (2):561-572. doi:10.1016/j.epsl.2004.02.032.

Obara, K. and Ito, Y., 2005. Very low frequency earthquake excited by the 2004 off the Kii Peninsula earthquake: a dynamic deformation process in the large accretionary prism. Earth Planets Space, 57:321-326.

Park, J.-O., Tsuru, T., Kodaira, S., Cummins, P.R., and Kaneda, Y., 2002. Splay fault branching along the Nankai subduction zone. Science, 297(5584):1157-1160. doi:10.1126/ science.1074111.

Reches, Z. and Ito, H., 2007. Scientific drilling of active faults: Past and future., In Harms, U., Koeberl, C., and Zoback, M.D. (Eds.), Continental Scientific Drilling, Heidelberg (Springer), 235-258, doi:10.1007/978-3-540-68778-8_6.

Saffer, D.M. and Marone, C., 2003. Comparison of smectite- and illiterich gouge frictional properties: application to the up-dip limit of the seismogenic zone along subduction megathrusts. Earth Planet. Sci. Lett., 215(1-2):219-235. doi:10.1016/S0012-821X(03)00424-2.

Tobin, H. and Kinoshita, M., 2006. NanTroSEIZE: the IODP Nankai Trough seismogenic zone experiment. Sci. Drill., 2:23-27, doi:10.2204/iodp.sd.2.06.2006.

\section{Authors}

Harold Tobin, Department of Geology and Geophysics, University of Wisconsin, 1215 West Dayton Street, Madison, Wis., 53706 U.S.A., e-mail: htobin@wisc.edu.

Masataka Kinoshita, IFREE (Institute for Frontier Research on Earth Environment), JAMSTEC (Japan Agency for Marine-Earth Science and Technology), 2-15 Natsushimacho, Yokosuka-city, Kanagawa 237-0061, Japan. 